\title{
Studies on soil health and plant growth promoting potential of Rhizobium isolates
}

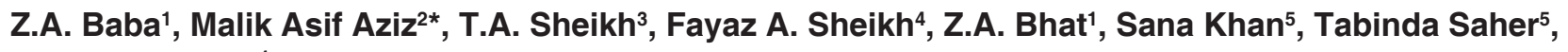 \\ Basharat Hamid ${ }^{1}$
}

${ }^{1}$ Regional Research Station, Wadura, Sopore, SKUAST-Kashmir-India; ${ }^{2}$ Krishi Vigyan Kendra (KVK) - Kargil, SKUAST-Kashmir-India; ${ }^{3}$ Mountain Live Stock research Institute, Mansbal, SKUAST-Kashmir-India; ${ }^{4}$ Division of Plant Breeding and Genetics, Shalimar, SKUASTKashmir-India; ${ }^{5}$ Division of Environmental Sciences, Shalimar, SKUAST-Kashmir-India

\section{A B S T R A C T}

A comperative study of organically and conventionally managed soils under beans was conducted to ascertain the physicochemical and microbiological characteristics of these soils. Average values of physicochemical and microbiological parameters of the rhizosphere soil samples from the selected districts were compared with the bean rhizosphere soils of the organic farm of Sher-e-Kashmir University of Agricultural Science and Technology of Kashmir India. The results revealed that the soil of the organic farm has significantly higher content of organic carbon (1.04\%), available Nitrogen, (298.7 $\left.\mathrm{kgha}^{-1}\right)$ phosphorus (16.72 kgha-1), potassium (296.30 kgha-1), dehydrogenase activity (68.7 $\mu \mathrm{g} \mathrm{TPF} / 24 \mathrm{hr} \mathrm{g}^{-1}$ soil), total viable bacteria $\left(78.90 \times 10^{6} \mathrm{cfu} \mathrm{g}^{-1}\right.$ soil), fungi $\left(48.73 \times 10^{3} \mathrm{cfu} \mathrm{g}^{-1}\right.$ soil), actinomycete $\left(27.20 \times 10^{3} \mathrm{cfu} \mathrm{g}{ }^{-1}\right.$ soil), phosphate solubilizing bacteria $\left(18.30 \times 10^{5} \mathrm{cfu} \mathrm{g}^{-1}\right.$ soil) and mycorrhizal spores $\left(4.10\right.$ spores $\mathrm{g}^{-1}$ soil) followed by that of district Kupwara rhizosphere soils with organic carbon $(0.97 \%)$, available Nitrogen $\left(293.0 \mathrm{~kg} \mathrm{ha}^{-1}\right)$, phosphorus $(15.81 \mathrm{~kg}$ ha-1), potassium $\left(252.3 \mathrm{~kg} \mathrm{ha}^{-1}\right)$, dehydrogenase activity $\left(62.7 \mu \mathrm{g} \mathrm{TPF} / 24 \mathrm{hr} \mathrm{g}^{-1}\right.$ soil), total viable bacteria $\left(72.60 \times 10^{6} \mathrm{cfu} \mathrm{g}^{-1}\right.$ soil), fungi $\left(45.76 \times 10^{3} \mathrm{cfu} \mathrm{g}^{-1}\right.$ soil), actinomycete $\left(24.3 \times 10^{3} \mathrm{cfu} \mathrm{g}^{-1}\right.$ soil), phosphate solubilizing bacteria $\left(14.8 \times 10^{5} \mathrm{cfu} \mathrm{g}^{-1}\right.$ soil) and mycorrhizal spores (3.8 spores $\mathrm{g}^{-1}$ soil). Rhizobium bacteria were also isolated from the effective nodules of the bean plants grown at different places of various districts in Kashmir valley, India. These isolates after identification were screened for the production of IAA, GA and siderophores. The isolate (Rhizobium phaseoli OF) from Organic farm was found most promising by producing $39.20 \mu \mathrm{l}, 162 \mu \mathrm{l}$, and $24 \mu \mathrm{l}$ of IAA, GA and siderophor respectively followed by $37.5 \mu \mathrm{l}, 153 \mu \mathrm{l}$, and $21 \mu \mathrm{l}$ of IAA, GA and siderophor respectively from the isolate obtained from rhizosphere soils of Kupwara district. The isolate (Rhizobium phaseoli OF) was used in combination with three levels of fertilizer nitrogen $(0,20$ and $40 \mathrm{~kg} \mathrm{ha}^{-1}$ ) in a field experiment with beans as experimental crop and five replications by adopting RBD design to study the impact on various plant growth and yield attributing features like number of pods per plant, pod weight and number of nodules. Nitrogen uptake, apparent nitrogen recovery and percent soil nitrogen utilization was also estimated. Maximum number of pods $\left(12\right.$ plant $\left.^{-1}\right)$ was recorded under the treatments $T_{5}$ and $T_{6}$. Significantly maximum pod weight $(5.96 \mathrm{~g})$ and number of nodules $\left(60.45\right.$ plant $\left.^{-1}\right)$ was observed under the treatment $T_{5}$. Treatments $T_{5}$ and $T_{6}$ were at par with respect to nitrogen uptake in grains (63 and $\left.64 \mathrm{~kg} \mathrm{ha}^{-1}\right)$, plant biomass $\left(84 \mathrm{~kg} \mathrm{ha}^{-1}\right)$ and total $\mathrm{N}$ uptake (147 and $148 \mathrm{~kg} \mathrm{ha}^{-1}$ ) by plant. Maximum apparent nitrogen recovery (210) and percent soil nitrogen utilization (46.37) was recorded from the treatment $T_{5}$.

Keywords: Rhizobium; Plant growth promoting activities; Nitrogen fertilizer; Soil health

\section{INTRODUCTION}

Soil health determines the overall capability of soil ecosystem to support the crop growth and microbial population. Biological and biochemical properties of soil, particularly those involved in energy flow and nutrient cycling, have been found to respond even minimal changes in soil conditions and management, thus furnishing information sensitive to subtle alteration of soil quality
(Pascual et al., 2000). Soil enzyme activities can be considered effective indicators of soil quality changes which occur as a result of environmental stresses and management practices. Soil enzyme analysis helps to assess the soil fertility,microbial activity and biochemical cycles of various elements in soils. Dehydrogenase activity is generally used as a measure of any disruption resulted by pesticides, heavy metals and management practices (McCarthy et al., 1994). Assessment of soil

\footnotetext{
${ }^{*}$ Corresponding author:

Malik Asif Aziz, Krishi Vigyan Kendra (KVK) - Kargil, SKUAST-Kashmir-India. E-mail: drasif_skuast@yahoo.com
} 
dehydrogenase enzyme shall be used as a diagnostic tool for better soil ecosystem assessment and amelioration. A large number of bacterial strains have been found to have beneficial impacts on the growth, yield and development of plants. Therefore their application for better plant health management and improving crop production has been the focused area of many studies for past so many years. This category of bacteria has been refered as plant growth promoting bacteria, which include the strains of genera like Pseudomonas, Azospirillum, Burkholderia, Bacillus, Enterobacter, Rhizobium, Erwinia, Serratia, Alcaligenes, Artbrobacter, Acinetobacter and Flavobacterium. Rhizobial bacteria have been proved to act as promising plant growth promoters. In the recent years the PGPR have attracted a cosmopolitain significance for their applications as a potential tool for sustaining agriculture production and improving soil health (Arshad et al., 2008). The mechanism by which the PGPR affects the plant growth positively can be of two types i.e., direct and indirect. Direct growth promotion can be due to the production of Indole compounds, gibberlic acid, nitrogen fixation, synthesis of ACC deaminase, solubilization of insoluble and unavailable mineral nutrients and mineralization of organic matter, while as indirect mechanism is the prevention of deleterious effect of pathogenic microorganisms. The IAA hormone leads to the plant root system development and subsequently enhances the uptake of nutrients from the soil. Soil bacteria of the family Rhizobiaceae which are gram negative, chemolitotrophic or chemo-organotrophic are called Rhizobia (Werner, 1992). This family has an array of bacterial genera; containing Rhizobium, Bradyrbizobium, Allorbizobium, Mesorbizobium, Sinorbizobium and Azorbizobium. From more than a century it has been known that growth of legumes can be promoted by Rhizobia via formation of nitrogen-fixing nodules only but several mechanisms have been proposed by which Rhizobia can directly stimulate the growth of plants including production of phytohormones (Humphry et al., 2007; Patten and Glick, 2000) increased uptake of nutrients (Biswas et al., 2000; Chabot et al., 1996), siderophore production which are compounds having low molecular weight and high affinity for iron (Meyer, 2000).

Beans and peas are popular vegetables that provide a rich source of proteins and carbohydrates. Edible pod are available early in the season before any other vegetables.In addition these play an important role in the crop rotation system by providing the nitrogen to the successive crop with out the added expense of supplimental fertilizer doses. Beans and peas are easy to grow and suffer few diseases and insect problems. Since pulses occupy an important position in the crop profile of Kashmir valley, therefore present study was aimed to assess the soil health of the legume growing soils of Kashmir valley.

\section{MATERIAL AND METHODS}

The present experiment was conducted at Regional Research station Wadura campus of SKUAST Kashmir during the years 2011-12 and 2012-13. A total of one hundred ten (110) bean rhizosphere soil samples were collected from five districts of kashmir valley and these were analysed for various physicochemical and microbial characteristics. Rhizobial isolates were also isolated from bean plants grown at different places in these districts. A total of fifty isolates were isolated from the beans roots. Ten plants at each location were uprooted and soil very close to roots was collected, pooled and packed in sterilized containers. The microbial assay was conducted immediately after the collection of the soil samples. The out standing screened Rhizobium isolate in combination with three levels of nitrogen $\left(\mathrm{N}_{0}, \mathrm{~N}_{20}, \mathrm{~N}_{40} \mathrm{~kg}^{-1}\right)$ was used in a field experiment following RBD design with five replications using french bean as experimental crop.

\section{Physico and biochemical properties of rhizosphere soils of beans}

A portion of the collected soil was air dried and processed for the estimation of various soil physicochemical properties. The $\mathrm{pH}$ and $\mathrm{EC}$ was measured in 1:2.5 soil water suspension with the help of a pH meter (Jackson, 1973), while as the electrical conductivity of the soil water extract was recorded with the help of a wheat stone bridge conductivity meter (Jackson, 1973). Organic carbon was determined by Walkly and Black rapid titration method as given by Pipper (1966), available nitrogen was estimated by Subbiah and Asija method (1956), available phosphorus was determined by Olsen's method as described by Jackson (1973), while as potassium was determined by flame photometer as described by Merwin and Peech (1950). The dehydrogenase avtivity was determined spectrophotometrically by following the method of Klein et al., (1971).

\section{Microbial properties of rhizosphere soils of beans}

The total viable bacteria, fungi, actinomycetes and phosphate solubilzing bacteria were enumerated by following dilution plating, agar media, incubation times and temperatures as described by Weaver et al. (1994). The arbuscular mycorrhizal spores were isolated and quantified by the method as described by Gerdemann and Nicolson (1963).

\section{Isolation of Rhizobium from nodules}

For isolation of rhizobial strains the bean plants were uprooted and the root system was washed thoroughly with tap water and large sized pink and healthy nodules were separated from the root system by using a sterilized blade, the nodules were then surface disinfected by dipping in $95 \%$ ethanol solution for 10 seconds followed by sterilization 
by $0.1 \%$ mercury chloride for three minutes (Russel et al., 1982). The nodules were then washed by sterilized water several times. The nodules were then crushed by a sterilized glass rod and mixed with $100 \mu \mathrm{l}$ sterilizes water. A loopful of the suspension was then streaked on YEMA medium and then incubated at $28 \pm 2{ }^{\circ} \mathrm{C}$ for $36 \mathrm{hrs}$. The single isolated colonies were then picked and restreaked on agar plates, this restreaking process was repeated several times to get pure culture of rhizobia.

\section{Identification of rhizobium strains}

The rhizobial isolates were identified on the basis of colony features, cell shape, size, motality, gram staining (Arora, 2003). The isolates were subjected to different biochemical tests like catalase, indole production, methyl red, Vogas prouskauer, citrate utilization (Lowe, 1962), starch hydrolysis, gelatin liquefaction (Arora, 2003).

The isolates were also tested for the fermentation of various sugars including Dextrose, Galactose, Mannose, Citrate, Lactose, Xylose, Fructose, Melibiose, L-arabinose, Glycerol, Mannitol (Krieg and Holt, 1984).

\section{Production of plant growth promoting substance}

All the Rhizobial isolates were subjected to qualitative estimation of IAA (Bric et al., 1991) and GA production (Brown and Burlingham, 1968). Luria agar supplemented with 0.06 per cent sodium dodecyl sulphate and one per cent glycerol was prepared and plated. The surface area of the agar medium was divided into squares of $2 \mathrm{~cm} \times 2 \mathrm{~cm}$ by marking on the bottom of each plate. The overnight culture of each isolate grown on Luria agar was spotted with sterile tooth pick in each square. The spotted plates were overlaid immediately with sterile disc of Whatman No. 1 filter paper. Plates were incubated until the colonies reached the size of 0.5 to $2.0 \mathrm{~mm}$ in diameter. The filter paper discs after incubation period were removed from the plates and treated by soaking in pertidishes containing Salkovaski's reagent (2\% of $0.5 \mathrm{~m} \mathrm{FeCl} 3$ in $35 \%$ perchloric acid). The treatment was allowed to proceed until adequate colour was developed. The IAA producing isolates were identified by the formation of characteristic red halo around the colony on filter paper. The paper discs after treatment were viewed under UV light. The spots giving typical green fluorescence were taken as positive for GA production.

The isolates showing IAA and GA production were further examined for quantitative estimation of IAA and GA production as detailed below.

\section{Quantitative estimation of IAA and GA Extraction}

The overnight cultures of the isolates which were positive for the production of IAA and GA in qualitative estimation were inoculated to $50 \mathrm{ml}$ of sterilized Czapeck's solution and incubated at $37^{\circ} \mathrm{C}$ for seven days in dark. After incubation, the cultures were centrifuged at $6000 \mathrm{rpm}$ for 20 minutes. The supernatant was collected in a conical flask and used for estimation of IAA and GA.

\section{Estimation of IAA (Gordon and Paleg, 1957)}

Twenty five $\mathrm{ml}$ of the supernatant was collected and the $\mathrm{pH}$ was adjusted to 2.8 using $1 \mathrm{~N} \mathrm{HCl}$ in a $100 \mathrm{ml}$ conical flask. Equal volume of diethyl ether was added to it and incubated in dark for four hours. Extraction of IAA was done at $40^{\circ} \mathrm{C}$ in a separating funnel using diethyl either. The organic phase was discarded and the solvent phase was pooled and evaporated to dryness. To the dried material, two $\mathrm{ml}$ of methanol was added and the IAA present in the methanol extract was determined. To $0.5 \mathrm{ml}$ of methanol extract, $1.5 \mathrm{ml}$ of distilled water and four ml Sapler's reagent ( $1 \mathrm{ml}$ of $0.5 \mathrm{M} \mathrm{FeCl} 3$ in $50 \mathrm{ml}$ of $35 \%$ perchloric acid) were added and incubated in dark for one hour. The intensity of pink colour developed was read at $535 \mathrm{~nm}$ in a UV-VIS spectrophotometer. From a standard curve prepared with known concentrations of IAA, the quantity of IAA in the culture filtrate was determined and expressed as $g$ per litre of broth medium.

\section{Estimation of GA (Paleg, 1965)}

Twenty five $\mathrm{ml}$ of the culture filtrate was taken in a test tube to which two $\mathrm{ml}$ of zinc acetate was added. After two minutes, two $\mathrm{ml}$ of potassium ferrocyanide was added and centrifuged at $1000 \mathrm{rpm}$ for 15 minutes. To five $\mathrm{ml}$ of this supernatant was added five $\mathrm{ml}$ of 30 per cent $\mathrm{HCl}$ and incubated at $20^{\circ} \mathrm{C}$ for 75 minutes. The blank sample was treated with five per cent $\mathrm{HCl}$ and the absorbance of the sample as well as blank was measured at $254 \mathrm{~nm}$ in a UV-visible spectrophotometer. The amount of GA present in the extract was calculated from the standard curve and expressed as $g$ per litre of the medium. The standard curves of IAA and GA were prepared by using graded concentrations of IAA and GA.

\section{Qualitative test for siderophore production}

Production of siderophore by rhizobial isolates was determined by plate assay. Chrome Azurol S blue agar medium (CAS) was used to detect siderophore production (Schwyn and Neilands, 1987). For preparing one litre of CAS medium, $60.5 \mathrm{mg}$ Chrome Azurol S (CAS) (HIMEDIA) was dissolved in $50 \mathrm{ml}$ water and mixed with $10 \mathrm{ml}$ iron (III) solution ( $1 \mathrm{mM} \mathrm{FeCl}_{3} \cdot 6 \mathrm{H}_{2} \mathrm{O}$ in $10 \mathrm{mM} \mathrm{HCl}$ ). While stirring, this solution was slowly added to $72.9 \mathrm{mg}$ hexadecyl trimethyl ammonium bromide (HDTMA) dissolved in $40 \mathrm{ml}$ water. The resultant dark blue liquid was autoclaved. To $100 \mathrm{ml}$ of Ashby's broth, $30.2 \mathrm{~g}$ of PIPES, $18 \mathrm{~g}$ of Difco Agar and $750 \mathrm{ml}$ double distilled water were added. The $\mathrm{pH}$ of the medium was adjusted to 6.8 by the 
addition of $\mathrm{NaOH}$ solution (w/v) and autoclaved. After cooling to $50^{\circ} \mathrm{C}$, the dye solution was added along the glass wall with gentle agitation to achieve mixing without formation of foam. The medium was poured into sterile petriplates. The plates were stored in a refrigerator $\left(4^{\circ} \mathrm{C}\right)$ for $24 \mathrm{~h}$ before use. The overnight grown bacteria were spotted on CAS plates and incubated at $30^{\circ} \mathrm{C}$ for $24 \mathrm{~h}$. The cultures showing yellow to orange coloured zone around the colonies were taken as positive for siderophore production.

\section{Quantitative estimation of siderophore production:}

Production of siderophore by the rhizobial isolates was estimated by the method described by Reeves et al. (1983). One hundred ml of Ashby's medium broth was inoculated with one per cent $\mathrm{v} / \mathrm{v}$ standard inoculum $\left(10^{9} \mathrm{cfu} / \mathrm{ml}\right)$ and incubated at $28 \pm 2^{\circ} \mathrm{C}$ for seven days. The culture was centrifuged at $12000 \mathrm{rpm}$ for $30 \mathrm{~min}$. Twenty $\mathrm{ml}$ of culture filtrate was extracted twice with equal amount of ethyl acetate after adjusting the $\mathrm{pH}$ to 2.0 with $0.1 \mathrm{~N} \mathrm{HCl}$. The ethyl acetate top phase was pooled, air dried and dissolved in $5 \mathrm{ml}$ of distilled water. Five $\mathrm{ml}$ of Hathway reagent $(1 \mathrm{ml}$ of $0.1 \mathrm{M} \mathrm{FeCl}_{3}$ and $1 \mathrm{ml}$ of $0.1 \mathrm{~N} \mathrm{HCl}$ to $100 \mathrm{ml}$ of distilled water followed by addition of $1 \mathrm{ml}$ of $0.1 \mathrm{M}$ potassium ferricyanide) was added to the assay solution and allowed to stand for the colour to develop. To estimate catechol type of siderophore, the absorbance was read at $700 \mathrm{~nm}$ with 2,3-dihydroxy benzoic acid as standard. The quantity of siderophore synthesized was expressed as $\mathrm{g}$ per $\mathrm{ml}$ of culture filtrate.

\section{Dehydrogenase activity}

The dehydrogenase activity was determined by placing 1 gm air dried soil sample in screw capped test tube, 0.2 and $0.5 \mathrm{ml}$ of $3 \% 2,3,5$ tetrazolium chloride and $1 \%$ glucose solution was added to the sample before incubation at $28 \pm 0.5^{\circ} \mathrm{C}$ for 24 hours, after incubation $10 \mathrm{ml}$ of methanol were added followed by vigrous shaking and then allowed to stand for 6 hours. The pink coloured supernatent was withdrawn and its optical density was recorded with a spectrophotometer at $485 \mathrm{~nm}$ wave length using a blue filter.The dehydrogenase activity was then recorded in terms of triphenyl formazan formed and expressed as $\mu \mathrm{g}$ $\mathrm{TPFh}^{-24} \mathrm{~g}^{-1}$ soil (Klein and Goulding, 1971)

\section{Plant growth characterer}

The average number of pods per plant, pod weight and number of nodules was recorder at the time of maturity of the crop.

\section{Nitrogen uptake and indicies}

The nitrogen uptake in grain and plant biomass was estimated after digesting the grain and plant sample by concentrated sulphuric acid $\left(\mathrm{H}_{2} \mathrm{SO}_{4}\right)$ in presence of digestion mixture.The following formullae were used for calculating the nitrogen uptake

Nitrogen uptake $(\mathrm{g})$ in grain per plant

$=\frac{\text { percent nitrogen concentration in grain } \text { plant }^{-1}}{100}$

$\times$ dry weight of grains per plant $(\mathrm{g})$

Nitrogen uptake $(\mathrm{g})$ in plant

$=\frac{\text { percent nitrogen concentration } \text { plant }^{-1}}{100}$

$\times$ dry weight of plant $(\mathrm{g})$

The apparent nitrogen recovery and percent soil nitrogen utilization was determined with the help of following formullae

Apparent nitrogen recovery $(A N R)=\frac{\mathrm{U}_{\mathrm{t}}-\mathrm{U}_{0}}{\mathrm{~N}_{\mathrm{a}}} \times 100$

Percent soil nitrogen utilization $(\mathrm{PSNU})=\frac{\mathrm{U}_{\mathrm{t}}}{\mathrm{N}_{\mathrm{a}}+\mathrm{A}_{\mathrm{N}}} \times 100$

Where, $\mathrm{U}_{\mathrm{t}}=$ uptake of nitrogen in test treatment $(\mathrm{kg} / \mathrm{ha})$, $\mathrm{U}_{0}=$ uptake of nitrogen in control $(\mathrm{kg} / \mathrm{ha}), \mathrm{N}_{\mathrm{a}}=$ Nitrogen applied to test treatment $(\mathrm{kg} / \mathrm{ha}), \mathrm{A}_{\mathrm{N}}=$ available soil nitrogen $(\mathrm{kg} / \mathrm{ha})$.

\section{Statistical analysis}

The data was statistically analysed by the method as described by Panse and Sukhatame (1985).

\section{RESULTS AND DISCUSSION}

The physico,biochemical and microbiological analysis of the rhizosphere soil samples revealed that the $\mathrm{pH}$ and $\mathrm{EC}\left(\mathrm{dSm}^{-1}\right)$ of all the samples was normal, while as significantly maximum organic carbon (1.04\%), phosphorus $\left(16.72 \mathrm{~kg} \mathrm{ha}^{-1}\right)$, dehydrogenase activity $(68.7 \mu \mathrm{g}$ $\mathrm{TPF} / 24 \mathrm{hr} \mathrm{g}^{-1}$ soil $)$, total viable bacteria $\left(78.90 \times 10^{6}\right)$, fungi $\left(48.73 \times 10^{3}\right)$, actinomycetes $\left(27.20 \times 10^{3}\right)$, PSB $\left(18.30 \times 10^{5}\right)$ and VAM spores $\left(4.10 \mathrm{~g}^{-1}\right.$ soil) was reported from the rhizosphere soil samples collected from the organic farm. The rhizosphere soils collected from kupwara were at par with that of organic farm soils with respect to available phosphorus and total VAM spore population. Similarly although non significant but maximum available nitrogen $\left(298.7 \mathrm{~kg} \mathrm{ha}^{-1}\right)$ and potassium $\left(296.3 \mathrm{~kg} \mathrm{ha}^{-1}\right.$ ) was also recorded from the organic farm soils (Tables 1 and 2). The most probable reason for the improved, organic carbon content, available nutrients and biological parameters in the organic farm soils may be the continuous and exclusive use of manures, biofertilizers, biopesticides and botanicals for nutrient pest and management. The management 
Baba, et al.: Rhizobium and soil health

Table 1: Physico- chemical properties of rhizosphere soils of beans

\begin{tabular}{|c|c|c|c|c|c|c|c|}
\hline $\begin{array}{l}\text { Sampling } \\
\text { location }\end{array}$ & $\mathrm{PH}$ & $\begin{array}{c}E C \\
\left(\mathrm{dSm}^{-1}\right)\end{array}$ & $\begin{array}{l}\text { OC } \\
(\%)\end{array}$ & $\begin{array}{c}\text { Available N } \\
\text { (kg/ha) }\end{array}$ & $\begin{array}{c}\text { Available P } \\
\text { (kg/ha) }\end{array}$ & $\begin{array}{c}\text { Available K } \\
\text { (kg/ha) }\end{array}$ & $\begin{array}{l}\text { Dehydrogenase activity } \\
\left(\mu \mathrm{g} \text { TPF } / 24 \mathrm{hr} \mathrm{g}^{-1} \text { soil) }\right.\end{array}$ \\
\hline Organic farm & 7.02 & 0.24 & 1.04 & 298.7 & 16.72 & 296.30 & 68.7 \\
\hline Pulwama & 7.30 & 0.31 & 0.92 & 291.3 & 15.24 & 248.7 & 57.2 \\
\hline Baramulla & 7.40 & 0.45 & 0.84 & 279.6 & 13.60 & 247.2 & 45.8 \\
\hline Kupwara & 7.14 & 0.29 & 0.97 & 293.0 & 15.81 & 252.3 & 62.7 \\
\hline Bandipora & 7.30 & 0.30 & 0.92 & 289.5 & 14.18 & 251.9 & 54.2 \\
\hline Anantnag & 7.32 & 0.31 & 0.90 & 281.7 & 14.02 & 248.4 & 53.1 \\
\hline SE \pm & 0.22 & - & 0.003 & 28.00 & 0.32 & 22.00 & 0.54 \\
\hline CD (0.05) & 0.64 & ns & 0.009 & 84.02 & 0.95 & 65.21 & 1.63 \\
\hline
\end{tabular}

Table 2: Microbiological properties of rhizosphere soils of beans

\begin{tabular}{|c|c|c|c|c|c|}
\hline \multirow{2}{*}{$\begin{array}{l}\text { Sampling } \\
\text { location }\end{array}$} & \multicolumn{4}{|c|}{ Population (cfu/g dry weight of soil) } & \multirow{2}{*}{$\begin{array}{c}\text { VAM } \\
\text { spores per } \\
\text { gram soil }\end{array}$} \\
\hline & $\begin{array}{c}\text { Total viable } \\
\text { bacteria }\left(\times 10^{6}\right)\end{array}$ & $\begin{array}{l}\text { Total viable } \\
\text { fungi }\left(\times 10^{3}\right)\end{array}$ & $\begin{array}{c}\text { Total viable } \\
\text { actinomycetes }\left(\times 10^{3}\right)\end{array}$ & $\begin{array}{l}\text { Total viable } \\
\text { PSB }\left(\times 10^{5}\right)\end{array}$ & \\
\hline Organic farm & 78.90 & 48.73 & 27.20 & 18.30 & 4.10 \\
\hline Pulwama & 68.10 & 38.81 & 23.10 & 12.3 & 2.6 \\
\hline Baramulla & 59.74 & 40.30 & 18.12 & 10.8 & 2.0 \\
\hline Kupwara & 72.60 & 45.76 & 24.3 & 14.8 & 3.8 \\
\hline Bandipora & 65.20 & 39.48 & 21.6 & 11.7 & 2.4 \\
\hline Anantnag & 62.00 & 41.61 & 20.4 & 11.3 & 2.1 \\
\hline SE \pm & 0.64 & 1.03 & 0.34 & 0.30 & 0.11 \\
\hline $\mathrm{CD}(0.05)$ & 1.88 & 1.09 & 1.01 & 0.94 & 0.36 \\
\hline
\end{tabular}

history of other studied soils revealed the heavy use of synthetic agrochemicals which might have adversly affected the soil health. These findings are in confirmity with the results of Gupta et al. (1980) who reported that organic carbon content of soils showed highly significant and positive correlation with the bacterial and fungal population. The dehydrogenase activity which acts as an indicator of microbiological redox system and is considered as a good measure of overall microbial activity and an index of soil microbial biomass. The maximum content of dehydrogenase in organic farm soils may be due to the highest organic carbon content which supports the microbial population. These findings are supported by the results of Stanislaw and Barbara (2012) who reported that presence of higher level of organic material significaltly increased the soil dehydrogenase activity.

\section{Production of plant growth promoting substances by the Rhizobium isolates}

The Rhizobium isolates isolated from the bean plants grown at different locations were screened for the production of various growth promoting sunstances like IAA, GA and siderophore. Screening of the Rhizobium isolates for the production of these plant growth promoting substances showed that all the Rhizobium isolates produced plant growth promoting substances (Table 3 ), but significantly maximum IAA (39.50), GA(162) and siderophore catechol type 2-3 DHBA was produced by the isolate Rhizobium phaseoli (OF). Similar results have been reported by Humphry (2007) who reported that Rhizobia species
Table 3: Production of plant growt promoting substances by Rhizobium isolates

\begin{tabular}{lccc}
\hline Isolates & IAA & GA & $\begin{array}{c}\text { Siderophore catechol } \\
\text { type 2-3 DHBA }\end{array}$ \\
\hline Rhizobium phaseoli (OF) & 39.20 & 162 & 24 \\
Rhizobium phaseoli (P) & 24.18 & 112 & 16 \\
Rhizobium phaseoli (B) & 37.50 & 153 & 21 \\
Rhizobium phaseoli (K) & 18.74 & 96 & 14 \\
Rhizobium phaseoli (BP) & 26.11 & 148 & 17 \\
Rhizobium phaseoli (AG) & 14.28 & 84 & 12 \\
SE士 & 0.32 & 1.24 & 0.35 \\
CD $(0.05)$ & 1.02 & 3.78 & 0.99 \\
\hline
\end{tabular}

have the ability to produce variable quantity of different plant growth promoting substances like IAA, gibberlic acid,cytokinins etc. The production of auxins, abscisic acid, cytokinins, gibberellins and siderophore is believed to be one of the most important mechanism influencing the growth of plant (Zahir et al., 2004).

\section{Impact of inoculation of Rhizobium isolates on plant} growth and yield attributes of french bean

The Rhizobium strains after isolation were screened for their plant growth promoting activities and the most effecient one was used in a field experiment in combination with the different levels of inorganic nitrogen to study their integrated effect on plant growth and yield attributes in french beans.

The field experiment results (Table 4) revealed that the number of pods per plant was significantly increased 
Table 4: Impact of inoculation of Rhizobium isolates on plant growth and yield attributes of french bean

\begin{tabular}{|c|c|c|c|c|c|c|c|c|}
\hline Isolates & $\begin{array}{l}\text { Average } \\
\text { no. of } \\
\text { pods } \\
\text { plant }^{-1}\end{array}$ & $\begin{array}{l}\text { Average } \\
\text { pod } \\
\text { weight } \\
\text { (g) }\end{array}$ & $\begin{array}{c}\text { Average } \\
\text { no. of } \\
\text { nodules } \\
\text { plant }^{-1}\end{array}$ & $\begin{array}{l}\text { Nitrogen } \\
\text { uptake } \\
\text { in grains } \\
\text { (kg/ha) }\end{array}$ & $\begin{array}{c}\text { Nitrogen } \\
\text { uptake in } \\
\text { plant biomass } \\
\text { (kg/ha) }\end{array}$ & $\begin{array}{l}\text { Total N } \\
\text { uptake } \\
\text { (kg/ha) }\end{array}$ & $\begin{array}{c}\text { Apparent } \\
\text { nitrogen } \\
\text { necovery }\end{array}$ & $\begin{array}{l}\text { Percent } \\
\text { soil } \\
\text { nitrogen } \\
\text { utilization }\end{array}$ \\
\hline $\mathrm{T}_{1}:$ Control & 7.94 & 3.41 & 35.18 & 41 & 64 & 105 & & \\
\hline $\mathrm{T}_{2}: \mathrm{N}_{20}$ & 9.0 & 4.0 & 42.27 & 55 & 73 & 128 & 115 & 40.37 \\
\hline $\mathrm{T}_{3}: \mathrm{N}_{40}$ & 9.0 & 4.24 & 38.33 & 58 & 77 & 135 & 75 & 40.06 \\
\hline $\mathrm{T}_{4}:$ Rhizobium phaseoli (OF) & 11.0 & 4.82 & 59.12 & 56 & 75 & 131 & - & \\
\hline $\mathrm{T}_{5}$ : Rhizobium phaseoli (OF) $+\mathrm{N}_{20}$ & 12.0 & 5.96 & 60.45 & 63 & 84 & 147 & 210 & 46.37 \\
\hline $\mathrm{T}_{6}:$ Rhizobium phaseoli (OF) $+\mathrm{N}_{40}$ & 12.0 & 5.0 & 58.0 & 64 & 84 & 148 & 107.5 & 43.91 \\
\hline SE \pm & 0.39 & 0.21 & 0.48 & 0.72 & 1.07 & 1.9 & - & - \\
\hline$C D(P=0.05)$ & 0.98 & 0.53 & 1.06 & 1.82 & 2.74 & 4.71 & - & - \\
\hline
\end{tabular}

Initial available Nitrogen $=297 \mathrm{~kg} / \mathrm{ha}$

by every treatment in comparision to control $(7.94$ pods plant $\left.^{-1}\right)$. The sole application of $20 \mathrm{~kg} \mathrm{Nha}^{-1}\left(\mathrm{~T}_{2}\right)$ and $40 \mathrm{~kg} \mathrm{Nha}{ }^{-1}$ were at par by producing 9 number of pods plant $^{-1}$. The maximum number of pods $\left(12\right.$ plant $\left.^{-1}\right)$ were recorded from the treatment combinations $\mathrm{T}_{5}$ : Rhizobium phaseoli $(\mathrm{OF})+\mathrm{N}_{20}$ and $\mathrm{T}_{6}$ : Rhizobium phaseoli $(\mathrm{OF})+\mathrm{N}_{40}$. These findings are in confirmity with the results obtained by Otieno et al. (2009) who reported that starter/low dose of fertilizer nitrogen would not adversly affect nodulation, but would benefit the legume when cotlydon nitrogen is depleted and fixed nitrogen is still unavailable, while as the higher level of fertilizer nitrogen significantly reduced the nodulation.

A good number of nodules (35.18 plant $^{-1}$ ) were also found in the control plots which reflected the presence of indigenous isolates capable of nodule formation (Table 4). The nodulation process was significantly increased by every treatment with the maximum number of nodules ( 60.45 plant $\left.^{-1}\right)$ recorded from the plants which received treatment $\mathrm{T}_{5}$ : (Rhizobium phaseoli $\left.(\mathrm{OF})+\mathrm{N}_{20}\right)$. The nodulation revealed that inoculation of Rhizobium isolate with lower level of nitrogen has been more effective as compared to the higher level of inorganic nitrogen. Similar findings were observed by Tahir et al. (2009) who reported nodule number increased significantly by $25 \mathrm{~kg} \mathrm{~N} \mathrm{ha}{ }^{-1}$ when applied in combination with Rhirobium inoculation in soybean. This significant increase in number of nodules due to inoculation reflects the better combining and symbiotic relationship between introduced rhizobia and French bean. However, the nodule formation was significantly reduced by the application of higher level of nitrogen $\left(\mathrm{N}_{40}\right)$ either alone or in combination with Rhizobium, indicating that higher levels of nitrogen decreased the efficiency of Rhizobium inoculation (Tahir et al., 2009).

There was a significant increase in the nitrogen uptake in grain under all the treatments over control (41 kg ha ${ }^{-1}$ ) (Table 4). Application of $40 \mathrm{~kg} \mathrm{~N} \mathrm{ha}^{-1}$ (T3) and Rhizobium inoculation (T4) alone were at par with respect to the nitrogen uptake in grain. Similarly the maximun value of nitrogen uptake in grain $\left(64 \mathrm{~kg} \mathrm{ha}^{-1}\right)$ was recorded from treatment $\mathrm{T}_{6}$ : Rhizobium phaseoli $(\mathrm{OF})+\mathrm{N}_{40}$ but it was at par with treatment $\mathrm{T}_{5}$ : Rbizobium phaseoli $(\mathrm{OF})+\mathrm{N}_{20}$. The similar pattern of nitrogen uptake in case of plant biomass was followed with a maximium of $84 \mathrm{~kg} \mathrm{ha}^{-1}$ observed under treatments $\mathrm{T}_{5}$ : Rbizobium phaseoli (OF) $+\mathrm{N}_{20}$ and $\mathrm{T}_{6}$ : Rhizobium phaseoli $(\mathrm{OF})+\mathrm{N}_{40}$. Consequently the total nitrogen uptake was also significantly improved by all the treatments with maximum value (148 $\left.\mathrm{kg} \mathrm{ha}^{-1}\right)$ recorded from the treatment $\mathrm{T}_{6}$ :Rhizobium phaseoli $(\mathrm{K})+\mathrm{N}_{40}$ (Table 4$)$.. Increase in $\mathrm{N}$ uptake in grain and total plant biomass due to Rhizobium inoculation alone and in combination with nitrogen fertilizer was mainly because of significant increased in nodulation, which inturn resulted in higher accumulation of $\mathrm{N}$ due to atomspheric $\mathrm{N}_{2}$ fixation. Significant increase in seed and shoot $\mathrm{N}$ of soybean inoculated with Rhizobium strains was previously reported by Patra et al., (2012) and Zhang et al. (2002).

The tretment $\mathrm{T}_{5}$ : Rhizobium phaseoli $(\mathrm{OF})+\mathrm{N}_{20}$ recorded maximum apparent nitrogen recovery (210) and percent soil nitrogen utilization (46.37) in comparision to the $\mathrm{T}_{6}$ : Rbizobium phaseoli $(\mathrm{OF})+\mathrm{N}_{40}$ (Table 4). This may be due to the reason that higher levels of nitrogen are detrimental to Rhizobium strains. These findings are supported by Tahir et al. (2009) and Otieno et al. (2007) who observed that nitrogen fertilizer application significantly reduced nodulation in most of the legume species.

\section{CONCLUSION}

The studied soils are biologically quite healthy with presence of efficient Rhizobial strains. The lower is the mineral nitrogen input, the greater is the yield performance of Rhizobium inoculated french bean. The study suggest that higher levels of inorganic nitrogen reduces the performance of efficient Rhizobium strains. 


\section{Author Contributions}

Z. A. B., designed the study, M. A. A. wrote the article, T. A. S., F. A. S., Z. A. B., S. K., T. S. and B. H. corrected the article.

\section{REFERENCES}

Arora, D. R. 2003. The Text Book of Microbiology. CBS Publisher, New Delhi. p41-48.

Arshad, M., B. Shaharoona and T. Mahmood. 2008. Inoculation with plant growth promoting rhizobacteria containing ACC-deaminase partially eliminates the effects of water stress on growth, yield and ripening of Pisum sativum L. Pedosphere. 18: 611-620.

Biswas, J. C., J. K. Ladha and F. B. Dazzo. 2000. Rhizobial inoculation improves nutrient uptake and growth of lowland rice. Soil Sci. Soc. Am. J. 64: 1644-1650.

Bric, J. M., R. M. Bostock and S. E. Silverstone. 1991. Rapid in situ assay for indole acetic acid production by bacteria immobilized on a nitrocellulose membrane. Appl. Environ. Microbiol. 57: 535538.

Brown, M. E. and S. K. Burlingham. 1968. Production of plant growth substances by Azotobacter chlorococum. J. Gen. Microbiol. 53: 135-144.

Chabot, R., H. Antoun and M. P. Cescas. 1996. Growth promotion of maize and lettuce by phosphate solubilizing Rhizobium leguminosarum biovar phaseoli. Plant Soil. 184: 311-321.

Gerdemann, I. W. and T. H. Nicolson. 1963. Spores of mycorrhizal endogone species extracted from soil by wet sieving and decanting. Trans. Britanica Mycol. Soc. 46: 235-244.

Gordon, S. A. and L. G. Paleg, 1957. Quantitative measurement of indole acetic acid. Plant Physiol. 10: 37-48.

Gupta, R. D., K. K. Jha, P. K. Sharma and R. D. Sud. 1980. Distribution of microorganisms in relation to physicochemical properties in soils of Jammu and Kashmir. J. Indian Soc. Soil Sci. 28(2): 259262.

Humphry, D. R., M. Andrews, S. R. Santos, E. K. James, L. V. Vinogradova, L. Perin, V. M. Reis and S. P. Cummings. 2007. Phylogenetic assignment and mechanism of action of a crop growth promoting Rhizobium radiobacter strain used as a biofertilizer on graminaceous crops in Russia. Antonie van Leeuwenhoek, 91: 105-113.

Jackson, M. L. 1973. Soil Chemical Analysis. $2^{\text {nd }}$ Median Reprint. Prentice Hall of India, New Delhi, p498.

Klein, D. A., T. C. Loh and R. Goulding. 1971. A rapid procedure to evaluate dehydrogenase activity of soils low in organic matter. Soil Biol. Biochem. 3: 385-387.

Krieg, N. R and J. G. Holt. 1984. Bergey's Manual of Systemic Bacteriology. Vol. 1. Williams and Wilkins, Baltimore/London. p240.

Lowe, G. H. 1962. The rapid method for detection of lactose fermentatation in paracolon organism by demonstration of 6-D-galactosidase. J. Med. Lab. Technol. 19: 21-25.

McCarthy, G. W., R. Siddaramappa, R. J. Reight, E. E. Coddling and G. Gao. 1994. Evaluation of coal influence on soil $\mathrm{pH}$ and enzyme activities. Biol. Fertil. Soils. 17: 167-172.
Merwin, H.D. and M. Peech, 1950. Exchangeable soil potassium in the sand, silt and clay fractions as influenced by the nature of complementary exchangeable cation. Soil Sci. Soc. Am. J. 15: 125-128.

Meyer, J. M. 2000. Pyoverdines: Pigments, siderophores and potential taxonomic markers of fluorescent Pseudomonas species. Arch. Microbiol. 174(3): 135-142.

Otieno, P. E., J. W. Muthomi, G. N. Cheminingwa and J. H. Nderitu, 2007. Effect of Rhizobium inoculation, farmyard manure and nitrogen fertilizer on growth nodulation and yield of selected food grain legumes. Afri. Crop Sci. Proc. 8: 305-312.

Paleg, L. G. 1965. Physiological effects of gibberellins. Annu. Rev. Plant Physiol. 16: 291-322.

Panse, V. S and P.V. Sukhatme. 1985. Statistical Methods for Agricultural Workers. ULV edition. ICAR, New Delhi, p.152-155.

Pascual, J. A., G. Garcia, T. Hernandez, J. L. Moreno and M. Ros. 2000. Soil microbial activity as a biomarker of degradation and remediation processes. Soil Biol. Biochem. 32: 1877-1883.

Patra, R. K., L. M. Pant and K. Pradhan. 2012. Response of soybean to inoculation with rhizobial strains: Effect on growth, yield, $\mathrm{N}$ uptake and soil N status. World J. Agric. Sci. 8(1): 51-54.

Patten, C. L. and B. R. Glick, 2000. Role of Pseudomonas putida indole-acetic acid in development of the host plant root system. Appl. Environ. Microbiol. 68(2002), 3795-3801.

Piper, C. S. 1966. Soil and plant analysis. Hons Publication, Bombay.

Reeves, M., P. L. Neilands and A. Ballows, 1983. Absence of siderosphore activity in Liegionella sp. grown in iron deficient media. J. Bacteriol. 154: 324-329.

Russell, A. D., W. B. Hugo and G. A. J. Ayliffes. 2004. Principles and Practices of Disinfection, Preservation and Sterilization. $4^{\text {th }}$ ed. Black Wall Scientific, London. p641.

Schwyn, B. and J. B. Neilands. 1987. Universal chemical assay for the detection and determination of siderophores. Ann. Biochem. 160: 47-56.

Stanislaw, K. and S. Barbara, 2012. Enzymatic activity of soil after applying various waste organic materials, ash and mineral fertilizers. Pol. J. Environ. Stud. 21(6): 1635-1641.

Subiah, B. V. and G. L. Asija. 1956. A rapid procedure for the determination of available nitrogen in soil. Curr. Sci. 31: 96.

Tahir, M. M., A. Kaleem, R. Nasir, K. Abdul and M. H. Kazmi. 2009. Effect of Rhizobium inoculation and NP fertilization on growth, yield and nodulation of soybean (Glycine max L.) in the subhumid hilly region of Rawalakot Azad Jammu and Kashmir, Pakistan. Afri. J. Biotechnol. 8(22), 6191-6200.

Weaver, R. W., S. Angel, P. Bottomley, D. Bezdick, S. Smith, A. Tabatabai and A. Wollum. 1994. Methods of Soil Analysis. Part 2. Microbiological and Biochemical Properties. Soil Science Society of America, Madison, Wisconsin, US, p.1121.

Werner, D. 1992. Symbiosis of Plants and Microbes. Chapman and Hall, London.

Zahir, A., M. A. Zahir, and T. F. J. William. 2004. Plant growth promoting rhizobacteria, applications and perspectives in agriculture. Adv. Agron. 81: 97-149.

Zhang, S., M. S. Reddy and J. W. Kloepper. 2002. Development of assays for assessing induced systemic resistance by plant growth-promoting rhizobacteria against blue mold of tobacco. Biocoontrol, 23: 79-86. 